\title{
On the Rural E-commerce Synergy Distribution System: Strategic Alliance, Basic Structure and Main Functions
}

\author{
Guanghua Zhao \\ School of Business Management \\ Zhejiang University of Finance and Economics \\ Hangzhou, China \\ zgh666999@163.com
}

\begin{abstract}
The Construction of rural e-commerce synergy set distribution system is mainly approach to solve the problem of rural e-commerce logistics distribution difficult, It was discussed mainly that the construction of the rural e-commerce synergy set distribution system in this paper, including the organization structure of league of rural cooperative set distribution was design, on the basis " structure flat, center of gravity down, village-level give priority to" train of thought, to establish the basic framework of synergy set distribution system, emphasized on the main operating functions to county level set distribution center and the villages and towns. It provides a new idea for solving the problem of "the last kilometer" and "the first kilometer" of the rural e-commerce.
\end{abstract}

Keywords-Rural e-commerce; Cooperative alliance; The county set distribution center; The village set distribution station

\section{INTRODUCTION}

The development of rural e-commerce is an important way for farmers to get rid of poverty and become well-off. However, the current problems of low efficiency and high cost in rural e-commerce logistics distribution seriously restrict the rapidly development of rural e-commerce. In this regard, existing relevant researches mainly discuss solutions from macro-policy support and infrastructure construction, and logistics subject cultivation, etc., but the research is rare on how to build a synergy set distribution system to improve the efficiency of rural e-commerce logistics distribution. these were discussing in this paper.

\section{Construction of Rural E-Commerce Cooperative Set Distrbution ALLIANCE}

The research results of Alvarez S A and Bareney $\mathrm{J} B$ (2001) is indicated that strategic alliance is an important foundation and organizational guarantee to improve the efficiency of supply chain[1]. Establishment rural e-commerce cooperative distribution alliance can effectively improve the efficiency of rural e-commerce cooperative distribution. rural e-commerce distribution alliance belongs to Complex Alliance in nature[2], its range of cooperation were relatively wide, almost contain all the business activities of the members and all of the value chain in addition to the core business and technology, partners in their respective entity status at the

\footnotetext{
Fund program: Natural Science Foundation of Zhejiang
} Province(LY17G020017) same time, the scope of cooperation both vertically cooperation in the supply chain of members themselves own, at the same time there are levels cooperation across different the supply chains. The vertical cooperation activities of single supply chain are complementary, while horizontal cooperation of cross-chain are competitive. Joint action coalition members may be more competitive in many ways than separate each other[3].

Extensively collected related literature and data to the construction of supply chain alliance, comparative analyzed using literature thematic analysis method, by CNKI and EBSCO and Chinese-foreign language network database, so as to establish the organizational structure of rural e-commerce synergy set distribution alliance.

The main members of the alliance are divided into three 1ayer, including the core leader 1ayer, the close layer member and the dynamic loose layer member. As a new type of strategic alliance, must have a core enterprise to dominate operation the league[4], hold the post of core enterprise is based on the local economy and society market environment, and the scale strength of participate the distribution , such as by a large e-commerce enterprises or large 3PL company or local agricultural materials enterprise, etc. Rural e-commerce synergy distribution alliance is a cooperative system, has the characteristics of self-organization evolution, its growth evolution of order parameter is the bottleneck resources of decision process and the direction of the alliance development (such as the outstanding management ability, or the resource in soft or hard assets of 3PL as well as e-commerce network operators and network platform enterprise or information technology enterprise, etc.), mastered the bottleneck resources is inner core power of alliance enterprise

Based on the principle of one leader with multifollowers, in addition to the core layer, synergy distribution alliance members include fixed layer, members of the fixed layer mainly related management department in the government of county and rural, information technology company or logistics companies it has a certain scale, warehousing, transportation and distribution enterprise, etc.) or agricultural materials operators, such as their core layer coordination command, through equity, investment, to enter into a long-term cooperation agreement to participate in 
decision-making, operation and cooperation of the alliance, both the credit and the union have close relationship[4]. In the loose floor, there are bus companies, rural cooperatives, convenience stores, individual agent, etc., which participate in the alliance business is temporary and dynamic, they participate in or exit Logistics business of the alliance depending on appear or disappear of the market opportunities.

\section{The Basic Framework Of Rural CoOperative DISTRIBUTION SYSTEM}

There are generally five links that including"supplier $\rightarrow$ county $\rightarrow$ township $\rightarrow$ village $\rightarrow$ farmer users " in the existing rural logistics distribution[4]. Accordance to the principle of "flattening structure and center of gravity was down", simplify the original vertical segmentation unnecessary village circulation link, building the new rural cooperative system including " suppliers $₹$ county set distribution center $₹$ the village set distribution station ₹farmers users" , there are two keys to the whole system: one of set distribution center in the county, the other is set distribution station in village. the set distribution center of county as a cargo transshipment hub, to undertake the docking between artery logistics and branch line distribution of rural e-commerce goods, also there ere many integrated functions such as warehousing, packaging, circulation processing, distribution, vehicle scheduling, goods distribution between county and village, supply chain information processing and so on, the key role is to integrate logistics resources and configuration optimization of logistics resource. The village set distribution station is mainly responsible for the implementation and distribution of the end of the village users and the collection activities of agricultural products into the city. To improve the full load rate of the vehicles, we should carry out the cargo allocation of cooperative direct transportation between the county set distribution center and the village set distribution station. The center of gravity of the distribution system will sink, to improve the efficiency of the village distribution station to the villagers. The basic architecture is shown in Fig. 1.

In the rural synergy Set distribution system, synergy distribution center in county is the central pivot of coordinated operation, while the village level synergy distribution station is the gravity center of the whole synergy distribution, because it is at the forefront of the upside logistics at the same time is the end of the decurrent logistics.

\section{The Main Function Of The County Set Distribution CENTER}

The county set distribution center plays an important role in the synergy distribution system of the whole rural ecommerce, to undertake almost all the logistics functions except the artery transportation of the trunk logistics. The county set distribution center is play a the role of operating allocation as the starting point and the end of artery transportation of e-commerce commodity and the regional distribution between county and village. The so-called called "Set" the function refers to the farmers are sold abroad, scattered, small batch of agricultural products by e-commerce in all the towns and villages after initial tally packaging, then transport to county set distribution center through the countyvillage road, set distribution center for LCL, palletized put into

batch vehicle transportation into the artery logistics as a scale capacity according to different goods, implementation the cohesion between county village cargo transport and artery

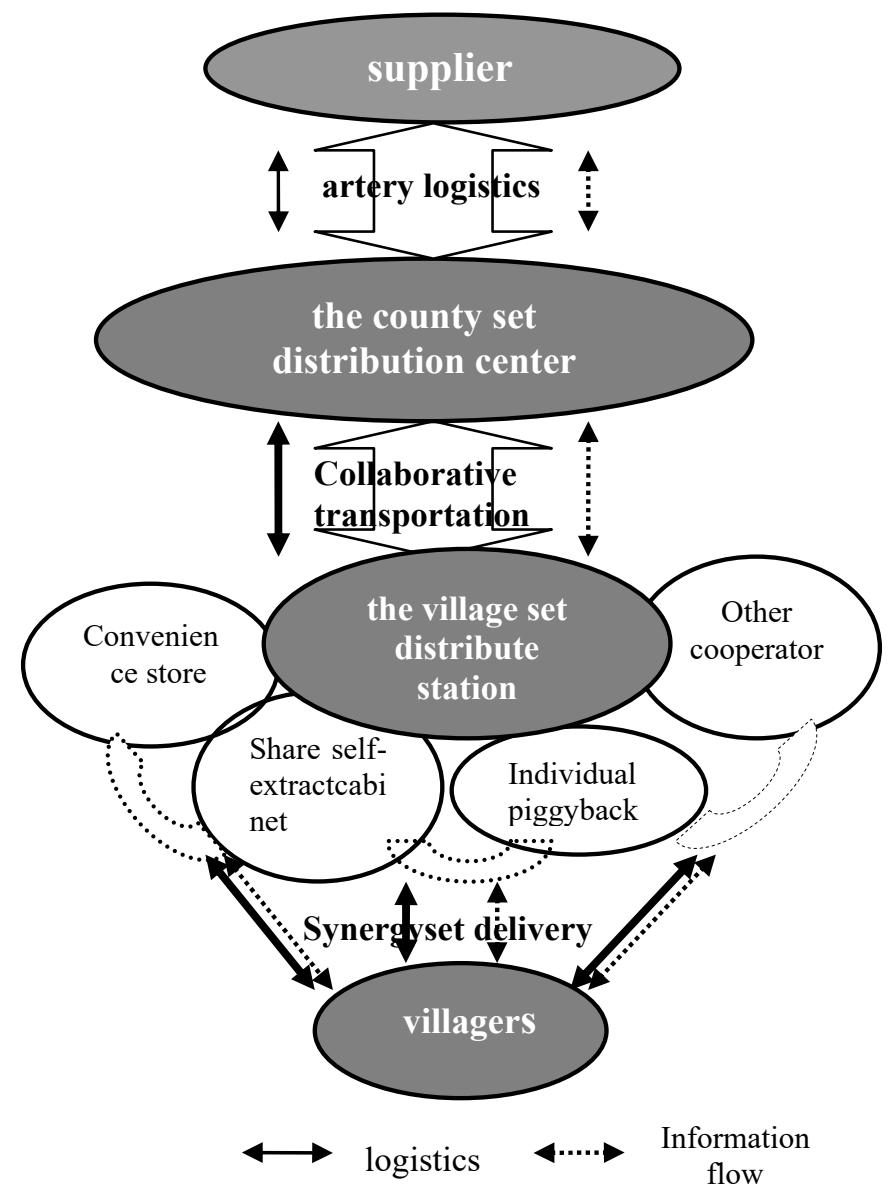

Fig. 1. Schematic diagram of rural synergy set distribution system.

logistics. Its " delivery " function refers to large quantities cargo sale by the e-commerce transport to the county set distribution center, will be carry out sorting and packing to goods deployment vehicle delivery to the village marshalling form smaller cargo units in accordance with the destination consignee in different villages-towns, and reasonable match station[5]. So, the main function of the county set distribution center is to carry out centralized or classified processing of ecommerce goods, so as to realize effective docking between arterial-branch transportation. Specific function are as follows:

\section{A. Management of Distribution Process and Dispatch and Integration of Logistics Resources}

In order to promote efficiency, implement scientific coordination on storage, packaging, circulation processing, distribution, vehicle scheduling combination, optimization of distribution path, information processing and other activities, dominated by core enterprise rely on the strong ability of supply chain management and advanced means of information technology in the county sets distribution center. At the same 
time, as an important collecting and distributing district and ecommerce goods circulation and processing place, and outflow and inflow of commodity, exhibition and marketing place, it should effectively coordinate logistics resources[5]. At the same time, it carries out timely visual monitoring, performance evaluation and other management activities for remote transportation and short-distance delivery vehicles and personnel. Effective integration and reasonable allocation of logistics resources are realized, promoted orderly and efficient operation of the whole rural e-commerce distribution system through the full play of these management and control functions.

\section{B. Goods Storage Function}

Play storage function is mainly based on two needs: one is that in order to guarantee the normal supply of agricultural products in circulation under the uncertain environment of market demand, a certain safety inventory needs to be maintained to serve as a buffer, so as to meet the needs of normal distribution, especially the need of immediate distribution, the storage of goods is one of the important means of profit.

In county set distributing center, static function of warehousing will have the effect of a reservoir, but also can create certain space value. Secondly, the goods collected by each village and town set distribution station after transported to the county set distribution center and waiting for the artery transported to various regions of the country or the world, or storaging goods from e-commerce suppliers in all the country or world transport to here waiting for sorting distribute to the villages and towns. Through appropriate container and reasonable sorting packing of the goods, set together with vehicles after the implementation of batch transportation and combined transport, maximum load, reduce the vehicle empty loading rate and logistics cost.

\section{The Functions of Packaging, Processing and Sorting of Goods}

There are three reasons that carry on repackages and simply and rationally reprocesses to the goods it are collected in the county set distribution center: firstly is the go direction of customer orders, convenient customer claim goods. Secondly, it is helpful to improve the efficiency of transportation and distribution of goods. Thirdly, conducive to promoting the sale of agricultural products and development of rural economic. The type of packaging carried out by the centralized distribution center mainly have logistics packaging, for convenient transportation, handling, storage, commodity protection, etc., but more of it is promotional packaging made according to the sales purposes of different customers.

As an important hub of the rural e-commerce synergy distribution system, the county set distribution center is faced with very complex objects for the centralized distribution. Not only the size of the customer varies greatly, but also the types of products are diverse, including various specifications, multiple batches, small batches and scattered delivery locations. Therefore set distribution center must be effectively deliver the goods according to the customers' category, the geographical scope, quickly and accurately for sorting, packaging, such as found that the goods have damage broken, and notify the relevant parties to exchange $\mathrm{w}$ and on this basis, according to the distribution plan to tally, make it adapt to the load transportation reasonable hold, this is a collection of the core functions of the county set distribution center.

\section{The Function of Distribution Goods}

Distribution between counties and villages is the core function of the county set distribution center, plays a decisive role in the command and management of distribution work. In order to implement this function perfectly, firstly, the branch distribution network between counties and villages should be established and perfected to achieve full coverage and no blind area. Secondly, the transportation vehicles should be properly combined to realize the optimal combination of man-vehiclecargo and seek the shortest delivery path. Thirdly, select and train distribution personnel, establish a lean distribution team, strengthen supervision and management, and establish a scientific profit allocation mechanism. Fourthly, ensure fast, accurate and safe delivery services to improve shopping experience and brand loyalty of rural users. The fifth is to vigorously implement synergy distribution, whether it is to deliver goods of multiple varieties, multiple specifications and small batches for the same user, or to deliver one or more goods for different users and the same train, strive to reduce resource waste and delivery cost with the premise of customer satisfaction.

\section{E. Function of Logistics Information Management}

Information flow is the nerve center of modern logistics and can effectively improve the future efficiency. The countylevel distribution center has a variety of functions, such as storage and storage, goods allocation, handling and handling, goods exhibition and sales, customer management, price negotiation, transport equipment deployment, operation arrangement and other logistics data information intersecting, sorting and releasing, undoubtedly becoming an information management center for rural e-commerce synergy distribution. As the bar code technology, RFID technology, EDI, GPS, MIS, GIS, Internet of things, big data, cloud computing and the technology of CRM, and other modern information technology applied in gradually, set the function of the distribution center of information center will be increasingly important, and become indispensable to the center of the set with the core functions, is also the key of "achieve zero inventory, quick response, timely delivery, ensuring the efficient e-commerce supply chain operation of agricultural products" . The county set distribution center is responsible for the application and management of the intelligent selfextract cabinet system set up in urban- rural and information platform[6]. Based on the Internet of things technology, the system has the functions of intelligent collection, information release, inquiry and the monitoring of cargo delivery process. Through the system, e-commerce enterprises, express companies, recipients, free couriers and village committee managers can be seamlessly connected. 


\section{F. Functions of Purchase, Exhibition and Set Goods of Agricultural Products}

In order to supply commodities at low cost for rural ecommerce customers, the county set distribution center must strengthen the scale of goods preparation, and integrate the needs of users in various regions, and purchase agricultural products in large quantities from the supplier of agricultural products in rural various regions to the distribution center and then transfer to users in various regions, which is the basic function of the county set distribution center. Some orders with large purchase volume are signed by the set distribution center and shipped directly from the field. The set distribution center should also have the function of commodity display and trade[7]. For example, there are buildings, exclusive shops, counters and so on. This is also an inevitable trend for the county set distribution center to expand its service function and develop to the advanced stage, because agricultural products can only be valuable if sold out. The multi-level and personalized services provided by the set distribution center can enable e-commerce enterprises and rural users to obtain more value-added services.

\section{The Main Function And Profit Approaches Of The Village Set Distribution STATions}

The village set distribution station undertakes the dual mission of "the last kilometer" of end distribution the of rural e-commerce and "the first kilometer" of delivered and takeaway agricultural products purchased online. It is the intersection of upward logistics and downward logistics, which determines the efficiency of the operation of the whole rural synergy set distribution system and is the top priority, we must attach great importance to the construction and operation of the village set distribution stations.

\section{A. Main Functions of the Village Set Distribution Station}

1) Direct deliver agricultural materials and agricultural products by net purchases to households, management of intelligent self-extract cabinet: Buying large on agricultural production data include pesticides, agricultural films, fertilizers, feed, agricultural machinery and accessories, veterinary drugs, seeds and other purchases, etc, variety of distribution are tanto, especially in the situation of large number of farmers outdoor-worker in the busy farming season, delivery agricultural materials it is farmers need to home or the fields by the village set distribution station. In addition, there are many kinds and wide range of daily necessities of farmers to online shopping[8]. Therefore, it is the basic function of the village set distribution station deliver these daily necessities timely and safely to farmers in the "last kilometer" of e-commerce logistics.

Using of intelligent self-extract cabinet contribute to solve the problem of the last kilometer of rural e-commerce logistics. Set the container according to the scope of delivery, demand of express business and population distribute characteristics in villages elements such as, building by the 3PL, e-commerce enterprise And so on after joint negotiation, the village committee is responsible for arrange set place, pick with administrators responsible for the daily operation management, and coordinate the relationship between the various express enterprise at the end of the distribution, this is the the important function of the village set distribution station.

2) Acquisition, preliminary processing and collection goods Precooling of agricultural products for improve the efficiency of "the first kilometer": The village set distribution station can purchase the origin agricultural products in the country according to the order demand of user in various regions, provide the collection mail service for the express company and charge some service fees. Carried out purchase and preliminary processing of sideline products in the country of origin cooperation with farmers according to the contract. Some fresh and special agricultural products still need precooling to ensure quality, the village set distribution station can purchase refrigeration, freezing and packaging equipment as various forms such as joint venture and cooperation, increase the sales time of agricultural products use preliminary processing and low-temperature storage for avoid or reduce waste of agricultural products. The village set distribution station will also carry out sorting, set goods and ship the agricultural products into the county set distribution center or directly transport various regions by artery logistics

3) Exhibition and sales in terminal related new agriculture products: Have multitudinous population and huge consumption potential in rural areas.farmers become the potential customers of enterprises struggle to develop. The village set distribution stations ware more and more attention as terminal of rural e-commerce market, multitudinous manufacturing companies (especially in household appliances, agricultural machinery, etc.) and e-commerce platform enterprise using it as a platform of product sales, the villages set distribution station for its promotional, sell goods, maintenance and other related services for earn profit. They are easy to gain the trust of local farmers and can achieve better results of exhibition and marketing because these activities are operated by native[9].

\section{B. Profit Approaches of the Village Set Distribution Station}

A scientific profit model should be implemented for the achieve development of healthy and sustainable of the village set distribution station. The main profit ways are as follows: firstly, the income from the e-commerce companies or express companies pay certain remuneration due to purchase of agricultural production and express delivered goods. Secondly, charge from concentrated transportation of agricultural products to county; Thirdly, play the profit function of intelligent self-extract cabinet, conduct rolling broadcast advertising in the display screen, charge and advertisement propaganda for enterprises, for increase sales revenue; The fourthly, the income from the purchase of agricultural products, the storage and refrigeration fees, the primary processing fees, the packaging and sorting fees; Fifthly, profit through charge of the "overdue package" and "overdue fine", etc. 


\section{THE CONCLUSION}

There are three key in constructing rural e-commerce synergy distribution system: firstly, it is necessary to establish rural e-commerce synergy set distribution alliance, which is an important basis and organizational guarantee for improving efficiency of rural e-commerce synergy distribution. The nature of alliance is composite alliance, main organizational structure includes core leading layer, compact layer and loose cooperation layer, each level has its own different division of labor and business of set distribution. Secondly, build new rural e-commerce set distribution system of "suppliers $\lessgtr$ the county set distribution center $\varsigma$ the village set distribution station $\varsigma$ farmers" basis on the "flat structure, the center of gravity sinking, give principal to with village", The center of set distribution in county is the operation hinge of the system, village set distribution station the operation basics and center of gravity of the system. Thirdly, we should strengthen and expand the operational functions of the county set distribution centers and the village set distribution stations. Functions of county distribution center is mainly integrates resources and coordinates variety logistics activities such as warehousing, packaging, circulation processing, distribution of goods, combination of vehicle dispatch and optimal of distribution path using strong supply chain management ability and relatively advanced information technology means, also focuses on the management of logistics distribution information platform. Village level set distribution station is mainly to doing good distribution job in the "last kilometer", and primary processing of agricultural products, collection of goods and agricultural product exhibition and marketing business in the "first kilometer", also to make profits through multiple channels for ensure its healthy development and sustainable operation.

\section{REFERENCES}

[1] S.A. Alvarez and J.B. Bareney, "How entrepreneurial firms can benefit from alliances with large partners," Academy of Management Executive, vol.15, pp. 139-148, June 2001.

[2] R.E. Spekman, T.M. Forbes, L.A. Isabella, and T.C. MacAvoy, "Alliance managemebt: A view from the past and a look to the future," Journal Management Stutis, vol. 35, pp. 8-20, March 1998.

[3] R Gulati, "Social structure and alliance formation: A longitudinal analysis," Administration Science Quarterly, vol. 40, pp. 93-94, March 1995.

[4] M.A. HittDacin, M.T. Levitas, and J.L. Arregle, "Partner selection in emerging and developed market contexts resource based and organizational learning perspectives," Academy of Management Journal, vol. 43, pp. 449-467, September 2000

[5] B.T. Ling, "Study on the countermeasure "first one kilometer" of agricultural product logistics," Value Engineering, vol. 347, pp. 124-125, August 2017.

[6] P. Jia, "Design of agricultural logistics organization based on dynamic alliance of supply chain," Agricultural Economy, vol. 651, pp. 34-36. October 2007.

[7] N. Aldin and F. Stahre, "Electronic commerce, marketing channels an logistics platforms a wholesaler perspective," European Journa of Operational Research, vol.144, pp. 270-279, February 2003.

[8] C. Dai, "Study on the construction of agricultural products logistics network in industrial integration development based on synergetic theory," Journal of Linyi University, vol. 590, pp. 86-90, February 2016.

[9] J. Feng. "Construction of rural logistics development system based on C2C e-commerce model," Business economics research, vol.702, pp.4041, August 2015. 